\title{
Dimension of Work Life Balance in Software Companies
}

\author{
Deivasigamani J. ${ }^{1, *}$, Dr. Shankar ${ }^{2}$ \\ ${ }^{1}$ Phd Scholar,VIT University \\ Chennai ,India \\ ${ }^{2}$ Associate Professor,VIT University \\ Chennai,India \\ *Corresponding author's email: Jdeivasigamani [AT] yahoo.com
}

\begin{abstract}
Work-Life balance is a concept with several connotations and varied consequences within and among different stakeholders. Over the past two decades the issue work-family and work-life balance have received significant attention from employers, workers, politicians, academics and the media. Concerns about work-life balance have become salient for number of reasons. Demographic and social changes have resulted in more women entering the workforce, working mothers becoming the norm rather than the exception. In this view, the researcher has done a study to understand the employees work life balance with reference to software companies in Chennai.
\end{abstract}

This study was conducted based on the objectives to know the work life balance of the employees in the software companies. There were 110 sample of respondents were chosen based on convenience sampling. Questionnaire was administered to collect the responses which have been formulated in such a way to meet the objectives of the study.

The results of the study brought out various interesting findings. However, this study also had thrown few suggestions for managing the work and life in software companies.

Keywords - Work life balance, Family, Organizational culture, Welfare

\section{INTRODUCTION}

Technological advancement (e.g., cell phones, e-mail, fax) have made it easier for work demand to intrude into family and personal life. Furthermore, the move towards global competition has increased pressure on organizations and individual employees alike to be more flexible and responsive to change.

However, it is in the context of current skill shortages and the prospect of an ageing workforce that it is now imperative for organizations to embrace work/life balance practices to attract and retain talent, not only from traditional sources but also from untapped and diverse social groups. These are social groups whose lifestyles can often demand greater attention to work/life balance working mothers, mature workers and some minority groups. For future commercial sustainability, organizations need to ensure they not just encourage but mandate a practical and workable work/life balance policy, benefiting and meeting the needs of both the organization and its employees. And importantly, organizations not providing real opportunity for employee work/life balance are opening themselves up to increasing numbers of dissatisfied and unproductive employees and hence increased attrition rates. Merely creating a work/life policy framework is not enough; fostering an organizational culture that supports the use of available policies is also of great importance.

In this climate, managing the boundary between home and work is becoming more challenging. There is a need for employers and employees alike to find flexible and innovative solutions that maximize productivity without damaging employees well - being, their family relationships and other aspects of life. Furthermore, the provision of work - life balance policies is likely to play a role in recruiting and retaining good - quality employees and maintaining a competitive edge in a demanding market place.

\section{Work-life Balance: Employer's Perspective}

For an employer a highly satisfied and hardly stressed employee is an invaluable asset and virile source of productivity. If a state of work-life balance is achieved by an employer, would result in high degree of fulfilment of the employer's objectives, by propelling him nearer to his business goals. 


\section{Work-Life Balance: An Employer's Aims: are as follows:-}

1. Improvement in the productive capacity of the employee

2. High sense of commitment of an employee to the organisation's welfare.

3. Development of high level of confidence in an employee.

4. Development of management skills in employees.

5. Retention of skilled workforce.

6. Maintenance of satisfactory level of customer relationship.

7. Positive reaction to competitive forces.

\section{Work-Life Balance: Employee's Perspective}

An employee should always keep the following factors in mind while at work in order to ensure a stress-free working in the workplace:

1. Drawing an appropriate schedule for the day, week or the month for dividing time between work and family.

2. Engaging him in a hobby.

3. - Using the permissible 'off's' available at workplace as per prevailing priorities between demands of profession and demands of mind, family and society.

4. Ensuring that his family participates in all social occasions sponsored by the organization, where employee's families are invited to participate.

5. Being in touch with family, even while working, during the day through telephone, email, etc.

6. Avoiding carrying the loads of work to home.

\section{Consequences of Work-Life Balance}

According to the Director, HR, Motorola India, Raghuram Reddum, Work-Life Balance has emerged as one of the biggest challenge for HR. Poor work life balance is often manifested in arrange of physical and psychological strains, such as irritability, depression, anxiety, diminished self-confidence, inability to relax, lack of sleep, burnout, low productivity, high employee turnover, safety hazards, increase in divorce cases, high blood pressure, ulcer, migraine and many other psychosomatic disorders.

Organisations also suffer owing to poor work life balance of their employees. The direct consequences are: poor productivity, high employee turnover, accidents etc.. Whereas the indirect consequences are low involvement, serious interpersonal conflict at work, aversion attitude towards work and so on. Lack of work life balance indirectly and negatively affects family dynamics. It results in marital discord, divorce, child abuse, and neglect of old parents. All these affect societal functioning and harmony.

\section{OBJECTIVES OF THE STUDY}

Primary objective;

To study employees perception towards work life balance.

Secondary Objective;

1. To know whether the employees are able to balance the work life and family life.

2. To identify whether the nature of the work is affecting their personal lives.

3. To identify the factors that impacts work - life balance.

4. To suggest some measures to improve work life balance.

\section{SCOPE OF THE STUDY}

1. The study is specific only to software professionals in Chennai.

2. The study is relates to work life balance policies and its awareness and perceived from the point of view of software professionals 


\section{NEED FOR WORK-LIFE BALANCE}

1. To benefit both the individual and the organisation

2. To be responsive to the needs of the organisation (nature of the business, operating hours etc) and demands of their service-users (citizens and/or government)

3. To recognize that the needs of both the organisation and employees are not static, but change over time.

4. To be available to all employees, or have it clearly stated where they are not (e.g. some jobs may not be able to be done part-time)

5. To value employees for their contribution to the organisation, regardless of their working pattern.

\section{LIMITATIONS OF THE STUDY}

1. The sample was limited to software companies in Chennai.

2. The study was conducted under the assumption that the information given by the respondents will be authentic

3. The outcome of the study cannot be generalized as the data is collected only from a section of employees and not from all the employees

4. The study is mainly concentrated only on the IT sectors. Hence it becomes difficult to judge the importance of worklife balance across other industries.

\section{RESEARCH METHODOLOGY}

\section{Research Design}

This study conducted was descriptive research in nature.

The sampling plan was convenience sampling. Under this sampling every item of the universe has an equal chance of inclusion in the sample. Here it is blind chance alone that determines whether one item or other is selected.

The sampling sizes were 110 employees across software companies.

\section{Collection of Data}

The various sources of data collection are:

Primary sources: Employees of various software companies in Chennai for the purpose of surveying about the work life balance.

Secondary sources: Websites, local libraries and previous study on work life balance.

\section{Methods of data collection}

Questionnaire method was used to collect the data. In this method, a questionnaire was given to the person concerned with the request to answer the question and the respondent has to answer the question on their own. This is one of the common and widely used methods for primary data collection. We can gather wide range of valuable information about the behaviour of the employee's viz. attitude, motive and options etc.

\section{FINDINGS}

In showcasing the results of the study, the researcher also provides the possible solutions to tackling issues pertinent to the study, by giving relevant suggestions. The researcher has presented main findings together with suggestions in a concise and comprehensible manner.

$49.1 \%$ of the respondents are in 8 to 9 hours in day they work.

Nearly $43.6 \%$ of the respondents are spending one hour in travelling to work.

$36.4 \%$ of the respondents are saying that they worry about work.

$70.9 \%$ of the respondents are saying that they feel happy about their time that they spend in their work.

The highest percentages $(60.9 \%)$ of the respondents are saying that they can manage the stress arising from the work by some entertainment.

$36.4 \%$ of the respondents said that company does not have a separate policy for work life balance.

$45.5 \%$ of the respondents have a desire for a holiday/paid time off.

$51.8 \%$ of the respondents are in the opinion that flexible hours in general will help them to balance their work life. 
Nearly $(44.5 \%)$ of the respondents agree that their organization provides them additional work provisions like health programs.

Almost $(36.4 \%)$ of the respondents is accepting that support from colleagues at work helps to balance work and family commitments.

The $(72.7 \%)$ of the respondents agree to work life balance policy in the organization should be customized to individual needs.

The highest percentages $(64.5 \%)$ of the respondents felt that they can meet the requirement of their job without working long hours.

Nearly $(52.7 \%)$ of the respondents agree that in their organization employees are encouraged to strike a balance between work and family lives.

$43.6 \%$ of the respondents agree that it is very hard to take care of personal or family matters during working days.

The highest percentages $(45.5 \%)$ of the respondents agree that they are often expected to take work home at night and or on weekends.

Most (50.9\%) of the respondents agree that they are regularly expected to put their jobs first before their families.

$44.5 \%$ of the respondents agree that the work schedule makes difficult for them to fulfil their domestic obligation.

Most (55.5\%) of the respondents agree that they cancel important social arrangement due to work.

The highest percentages $(56.4 \%)$ of the respondents agreed that they cancel or change holidays due to pressure of work.

The $(62.7 \%)$ of the respondents agree that managers in the organization are quite accommodating of family related needs.

\section{SUGGESTIONS}

1. An organization must come up with effective and efficient work life balance policies

2. An organization can provide a flexible hours in general helps to balance work life

3. Additional provisions can be provided to the employees( Such as health program, Counselling, Parenting Care, Telecommuting etc.,)

4. Work life balance programs can be customized to individual needs

5. There can be some flexibility in hours during the workdays to take care of the personal and family matters

6. Employees carrying work from home at night and or on weekends should be analyzed and considered carefully.

7. The work schedule present makes them difficult to fulfil domestic obligations, so it can be rescheduled

8. Work load make the employees cancel important social arrangement which should be analysed and make alternatives.

\section{FUTURE WORK}

This study outcome cannot be generalized since the focus is on software companies in Chennai. It is recommended that future study on work life balance can cover on global scenario and various other types of industries.

\section{CONCLUSION}

Software companies should come up with effective and efficient work life balance policies and programs. This will help to reduce the work life conflict for software employees. Further leaders in the organization should take initiation to improve work life policies for their employees as it plays a significant role in the organization and improve individual and organizational performance. This will help to increase organizational commitments, improve productivity, efficiency, retain best talent and motivate IT employees to give their best.

Work life balance is thus a dynamic phenomenon. It is not a structure but a process. The flexibility of work alleviates stress and helps in better time management. The study confirms that a proper work life balance will provide job satisfaction of employees which in form will create organizational success and develop competitive advantage for software companies.

The key role of human resource therefore, is to understand the critical issue of work life balance, integrate it into the organization HR policy, and champion work life balance program. A sentence that bring the idea of work life balance to the point is "Work to live, don't live to work". 


\section{REFERENCES}

1. Amstad, F.T., Meier, L.L., Fasel, U., Elfering, A. and Semmer, N.K. (2011), "A meta-analysis of work-family conflict and various outcomes with a special emphasis on cross-domain versus matching-domain relations", Journal of Occupational Health Psychology, Vol. 16 No. 2, pp. 151-169.

2. Bailyn, L. (1997). The impact of corporate culture on work-family integration. In S. Parasuraman \& J. H. Greenhaus (Eds.), Integrating work and family: Challenges and choices for a changing world (pp. 209-219). Westport, CT: Quorum.

3. Bloom, N., Kretschmer, T. and Van Reenen, J. (2011), "Are family-friendly workplace practices a valuable firm resource?”, Strategic Management Journal, Vol. 32 No. 4, pp. 343-367.

4. Bond, J. T., Galinsky, E., \& Swanberg, J. E. (1998). Synthesis of findings: The 1997 national study of the changing workforce. New York: Families and Work Institute.

5. Christensen, P. M. (1997). Toward a comprehensive work-life strategy. In S. Parasuraman \& J. H. Greenhaus (Eds.), Integrating work and family: Challenges and choices for a changing world (pp. 25-37). Westport, CT: Quorum.

6. Edwards, J. R., \& Rothbard, N. P. (2005). Work and family stress and well-being: An integrative model of person-environment fit within and between the work and family domains. In E. E. Kossek \& S. J. Lambert (Eds.), Work and life integration: Organizational, cultural, and individual perspectives (pp. 151-169). Mahwah, NJ: Lawrence Erlbaum Associates.

7. Friedman, D. E. \& Johnson, A. A. (1997). Moving from programs to culture change: The next stage for the corporate work-family agenda. In S. Parasuraman \& J. H.

8. Frone, M. R. (2003). Work-family balance. In J. C. Quick \& L.E. Tetrick (Eds.), Handbook of occupational health psychology (pp. 143-162). Washington, DC: American Psychological Association.

9. Greenhaus (Eds.), Integrating work and family: Challenges and choices for a changing world (pp. 192-208). Westport, CT: Quorum.

10. Greenhaus, J. H., \& Parasuraman, S. (1997). The integration of work and family life: Barriers and solutions. In S. Parasuraman \& J. H. Greenhaus (Eds.), Integrating work and family: Challenges and choices for a changing world (pp. 232-240). Westport, CT: Quorum. 